\title{
PENGARUH BAP (Benzyl Amino Purine) DAN AIR KELAPA TERHADAP PERTUMBUHAN TUNAS PUCUK DAN KANDUNGAN SULFORAFAN BROKOLI (Brassica oleracea L. var. italica Plenck) SECARA IN-VITRO
}

\author{
Alfrida Maninggolang \\ Jeany Sh. Polii-Mandang \\ Wenny Tilaar
}

\begin{abstract}
This study aims to know the effect of Benzyl Amino Purine (BAP) and Coconut Water on shoot bud growth and Broccoli Sulforaphane content (Brassica oleracea L. var italic Plenck). The study was conducted in the laboratory of Biotechnology Department of Aquaculture, Faculty of Agriculture of Sam Ratulangi University, Manado, that conducted from August-December 2017. This study used a Complete Randomized Design (RAL), consisting of 8 treatments and each repeated as many 4 times, so we get 32 unit experiment. The variables observed were number of buds, number of leaves, plant height, wet weight, root number and Sulforaphane content analysis. The result of research shows that analysis of variance showed that in the use of Benzyl Amino Purine (BAP) concentration 3 ppm tends to increase the number of leaves aged 4 Weeks After Culture (MSK) and increase the number of shoots age 2 and 6 Weeks After Culture (MSK). Benzyl Amino Purine (BAP) 3 ppm can increase the wet weight of age $6 \mathrm{~W}$ eeks After Culture ((MSK). Coconut water 20\% tends to increase the number of leaves at age 6 Weeks After Culture (MSK) and increase the number of shoots aged 6 Weeks After Culture (MSK), while for combination of 3 ppm Benzyl Amino Purine (BAP) and coconut water $20 \%$ tends to increase the number of leaves aged 2 Weeks After Culture (MSK) and the number of shoots aged 2 Weeks After Culture (MSK). Combination of coconut water and Benzyl Amino Purine (BAP) is not detected by the content of Sulforaphane.
\end{abstract}

Keywords: Brassica oleraceae var italic plenck, Benzyl Amino Purine (BAP), Coconut Water, Sulforaphane

\begin{abstract}
ABSTRAK
Penelitian ini bertujuan untuk mengetahui pengaruh pemberian Benzyl Amino Purine (BAP) dan Air Kelapa terhadap pertumbuhan tunas pucuk dan kandungan Sulforafan Brokoli (Brassica oleracea L. var. italic Plenck). Penelitian dilaksanakan di laboratorium Bioteknologi Jurusan Budidaya, Fakultas Pertanian Universitas Sam Ratulangi, Manado, pada bulan Agustus-Desember 2017. Penelitian ini menggunakan Rancangan Acak Lengkap (RAL), yang terdiri dari 8 perlakuan dan masing-masing diulang sebanyak 4 kali, sehingga didapatkan 32 satuan percobaan. Variabel yang diamati ialah jumlah tunas, jumlah daun, tinggi tanaman, berat basah, jumlah akar dan analisis kandungan sulforafan. Hasil analisis sidik ragam memperlihatkan bahwa pada penggunaan konsentrasi BAP 3 ppm cenderung meningkatkan jumlah daun umur 4 Minggu Setelah Kultur (MSK) dan meningkatkan jumlah tunas umur 2 dan 6 minggu setelah kultur (MSK). Benzyl Amino Purine (BAP) 3 ppm dapat meningkatkan berat basah umur 6 minggu setelah kultur (MSK). Air kelapa $20 \%$ cenderung meningkatkan jumlah daun pada umur 6 minggu setelah kultur (MSK) dan meningkatkan jumlah tunas umur 6 minggu setelah kultur (MSK), sedangkan untuk kombinasi 3 ppm Benzyl Amino Purine (BAP) dan air kelapa $20 \%$ cenderung meningkatkan jumlah daun umur 2 minggu setelah kultur (MSK) dan jumlah tunas umur 2 minggu setelah kultur (MSK). Pemberian kombinasi air kelapa dan Benzyl Amino Purine (BAP) tidak terdeteksi kandungan sulforafan.
\end{abstract}

Kata kunci: Broccoli (Brassica oleraceae var italic plenk), Benzyl Amino Purine (BAP), air kelapa, Sulforafan 


\section{PENDAHULUAN}

\section{Latar Belakang}

Sulforafan merupakan senyawa antioksi-dan paling ampuh yang tersimpan pada tanaman brokli, selain betakaroten, indola, kuersetin, dan glutation. Brokoli juga sangat kaya akan mikromineral kromium, yang membantu meredam melonjaknya kadar gula darah pada penderita kencing manis (Diabetes mellitus), sehingga pemanfaatan sayuran brokoli ini sangat disarankan untuk penderita kencing manis (Apriadji, 2008). Sehubungan dengan fungsi tanaman Brokoli ini sebagai tanaman obat yang mengandung metabolit sekunder, terutama sulforafan, maka perlu dikembangkan, yang ditujukan pada peningkatan sulforafan dalam kultur yang terkait dengan pengaruh perangsangan zat pengatur tumbuh (Rumondor, 2013)

Senyawa glukorafanin serta sulforafan banyak terdapat pada Brassica dan Euporbiaceae. Hasil penelitian tentang pengaruh NAA dan BAP menunjukan bahwa terdapat interaksi antara NAA dan BAP dalam pengaruhnya terhadap kandungan sulforafan pada brokoli secara in vitro. Kandungan sulforafan tertinggi terdapat pada perlakuan kombinasi NAA 1 ppm dan BAP 5 ppm yaitu $24.32 \mathrm{mg} / \mathrm{l}$ (Tilaar, 2016). Salah satu faktor penentu keberhasilan kultur jaringan tumbuhan adalah pengaruh Zat Pengatur Tumbuh. Selain penggunaan zat pengatur tumbuh sitokinin sintetik maka dalam penelitian ini juga dilakukan penambahan air kelapa sebagai alternatif pengganti zat pengatur tumbuh pada media.

Zat Pengatur tumbuh golongan sitokinin yang sering digunakan dalam kultur jaringan adalah BAP dan Kinetin (George \& Sherrington, 1984). BAP adalah sitokinin yang sering digunakan karena paling efektif untuk merangsang pembentukan tunas, lebih stabil dan tahan terhadap oksidasi serta paling murah diantara sitokinin lainnya (Nurjanah, 2009). Penelitian yang dilakukan oleh (Tilaar \& Rantung, 2013) menjelaskan bahwa BAP 2 ppm mampu mempercepat waktu bertunas.
Air kelapa merupakan senyawa organik yang sering digunakan dalam aplikasi teknik kultur jaringan. Menurut Bey, Syafii, \& Sutrisna (2006) perlakuan air kelapa secara tunggal pada konsentrasi $250 \mathrm{ml} / \mathrm{l}$ mampu menghasilkan pembentukan daun dan akar lebih cepat pada kultur in vitro anggrek (Phalaenopsis amabilis BL.). Mandang (1993) mendapatkan bahwa kandungan klorofil jaringan krisan in vitro umur 10 MSK pada media yang diberi air kelapa $20 \%$, BAP dan IAA terhadap berat daun segar sebesar $1.551 \mathrm{mg} / \mathrm{g}$.

Hasil penelitian diatas menunjukan bahwa air kelapa mendorong pertumbuhan beberapa tanaman dalam kultur jaringan. Hal ini diduga dapat disebabkan karena (Mandang, 2013) : 1) Air kelapa mengandung komponenkomponen hampir sama dengan media MS karena mengandung : gula, unsur-unsur hara makro dan mikro, asam amino dan asam organik; 2) Air kelapa sebagai bahan subitusi media MS : pada kultur jaringan krisan diperoleh bahwa subtitusi media MS dengan air kelapa sampai $40 \%$ mengahasilkan berat basah tunas yang lebih tinggi dibanding yang menggunakan MS 100\%; 3) Air kelapa sebagai pelengkap media MS artinya ditambahkan pada media yang komposisinya lengkap (100\%). Penambahan air kelapa berkisar dari $15 \%$ samnpai $30 \%$; 4) Air kelapa sebagai buffer : pada kultur jaringan krisan yang medianya disubtitusi sebagian dengan air kelapa maka penurunan $\mathrm{pH}$ dapat ditekan.

Diduga ada pengaruh pemberian BAP dan air kelapa terhadap pertumbuhan kotiledon dan kandungan Sulforafan Brokoli.

\section{Rumusan Masalah}

Berdasarkan latar belakang yang sudah diuraikan sebelumnya, masalah-masalah yang dapat ditarik yaitu :

1. Berapa besar konsentrasi kombinasi BAP dan Air Kelapa yang tepat untuk pertumbuhan tunas pucuk dan kandungan sulforafan Brokoli secara in vitro.

2. Bagaimana respon pertumbuhan eksplan tanaman brokoli terhadap pemberian BAP dan Air Kelapa secara in vitro. 


\section{Tujuan Penelitian}

Tujuan penelitian ini untuk mengetahui pengaruh pemberian BAP dan Air Kelapa terhadap pertumbuhan tunas pucuk dan kandungan sulforafan Brokoli secara in vitro.

\section{Manfaat Penelitian}

Manfaat dari penelitian ini yaitu:

1. Mendapatkan metode perbanyakan tunas pucuk Brokoli secara in vitro.

2. Memperoleh konsentasi zat pengatur tumbuh BAP dan Air Kelapa yang optimum untuk pertumbuhan tunas pucuk Brokroli secara in vitro.

3. Memperoleh kombinasi zat pengatur tumbuh BAP dan Air Kelapa yang optimum untuk pertumbuhan tunas pucuk Brokroli secara in vitro.

4. Memberikan informasi dasar bagi peneliti lebih lanjut mengenai kajian kultur in vitro pada tanaman Brokoli.

\section{METODOLOGI PENELITIAN}

\section{Tempat dan Waktu Penelitian}

Penelitian ini dilaksanakan di Laboratorium Biotegnologi Universitas Sam Ratulangi Manado Sulawesi Utara pada (Bulan Agustus 2017- Selesai).

\section{Bahan dan Alat Penelitian}

Bahan yang digunakan dalam penelitian ini meliputi: Bibit Brokoli, agar sebagai pemadat, sukrosa, Air Kelapa varietas tenga umur 7 bulan, BAP, Klorox, Alkohol $70 \%$ dan $95 \%$, Betadine dan Aquadest steril, dan bahan lain yang mendukung penelitian ini. Media dasar yang digunakan adalah media MS (Murashige and Skoog) ditambah dengan beberapa rasio konsentrasi BAP dan Air Kelapa.

Alat yang digunakan dalam penelitian ini adalah peralatan gelas (botol kultur, gelas ukur, beaker glass, erlenmeyer, dan petridish), timbangan analitik, $\mathrm{pH}$ meter, autoclave, Laminar Air Flow (LAF), peralatan diseksi (pinset, gunting dan skalpel), stirer, lampu spiritus, rak kultur dengan lampu 40 watt dan alat lain yang mendukung penelitian ini.

\section{Metode Penelitian}

Penelitian ini menggunakan Rancangan Faktorial dalam Rancangan Acak Lengkap yaitu kombinasi antara Air Kelapa dalam 2 taraf dan BAP dalam 4 taraf, sehingga di dapatkan 8 kombinasi perlakuan dan di ulang sebanyak 4 kali. Susunan perlakuan penelitian dapat dilihat pada Tabel 1.

Tabel 1. Susunan Perlakuan Dalam Penelitian

\begin{tabular}{ccc}
\hline Perlakuan & \multicolumn{2}{c}{ Komposisi Media } \\
\hline & Air Kelapa $(\boldsymbol{\%})$ & BAP $(\mathbf{p p m})$ \\
\hline A & 0 & 0 \\
B & 0 & 1 \\
C & 0 & 2 \\
D & 0 & 3 \\
E & 20 & 0 \\
F & 20 & 1 \\
G & 20 & 2 \\
H & 20 & 3 \\
\hline
\end{tabular}

Metode matematik Rancangan Acak Lengkap menurut Gomez and Gomez (1995) sebagai berikut : $Y_{i j}=\mu+\alpha i+\varepsilon i j$

Dimana :

$$
\begin{aligned}
\mathrm{Y}_{\mathrm{ij}} & = & \text { Hasil pengamatan pada perlakuan } \\
& & \text { ke-i ulangan ke-j } \\
\mu & = & \text { Rataan umum } \\
\text { ai } & = & \text { Perlakuan ke-i } \\
\varepsilon \mathrm{ij} & = & \text { Pengaruh galat dari perlakuan ke-I } \\
& & \text { ulangan ke-j } \\
\mathrm{i} & = & 1,2,3, \ldots 8 \\
\mathrm{j} & = & 1,2,3,4
\end{aligned}
$$

\section{Variabel Pengamatan}

Variabel yang diamati pada penelitian ini:

1. Jumlah tunas di hitung saat 2, 4, 6 minggu setelah kultur.

2. Tinggi tunas di saat 6 minggu setelah kultur.

3. Jumlah daun di hitung saat 2, 4, 6 minggu setelah kultur.

4. Jumlah akar di hitung saat 6 minggu setelah kultur.

5. Berat basah di timbah saat umur 6 minggu setelah kultur.

6. Analisis kandungan Sulforafan

\section{Analisis Data}

Data yang diperoleh dari hasil pengamatan dianalisis dengan analisis ragam. Apabila berbeda nyata, maka dilanjutkan dengan uji Beda Nyata Terkecil (BNT). 


\section{HASIL DAN PEMBAHASAN}

\section{Jumlah Daun}

Analisis ragam jumlah daun umur 2, 4 dan 6 MSK menunjukkan bahwa perlakuan BAP tidak memberikan pengaruh nyata terhadap jumlah daun umur 2 dan 6 MSK, tetapi memberikan pengaruh nyata terhadap jumlah daun umur 4 MSK yaitu 6.38 namun tidak berbeda dengan perlakuan B0 dan B1 tapi berbeda dengan perlakuan B2. Pengaruh BAP terhadap jumlah daun umur 4 MSK disajikan pada Tabel 2 dan Gambar 1.

Tabel 2. Pengaruh BAP Terhadap Jumlah Daun Umur 4 MSK (minggu setelah kultur)

\begin{tabular}{|c|c|}
\hline Perlakuan & Rata-rata Jumlah Daun \\
\hline \multicolumn{2}{|l|}{$\mathrm{BAP}(\mathrm{mg} / \mathrm{l})$} \\
\hline $\mathrm{B} 0(0 \mathrm{ppm})$ & $5.13^{\mathrm{ab}}$ \\
\hline $\mathrm{B} 1(1 \mathrm{ppm})$ & $6.25^{\mathrm{b}}$ \\
\hline $\mathrm{B} 2(2 \mathrm{ppm})$ & $3.25^{\mathrm{a}}$ \\
\hline B3 (3 ppm) & $6.38^{\mathrm{b}}$ \\
\hline BNT 5\% & 2.90 \\
\hline
\end{tabular}

Keterangan: Angka yang diikuti dengan huruf yang sama, tidak berbeda nyata berdasarkan uji BNT 5\%.
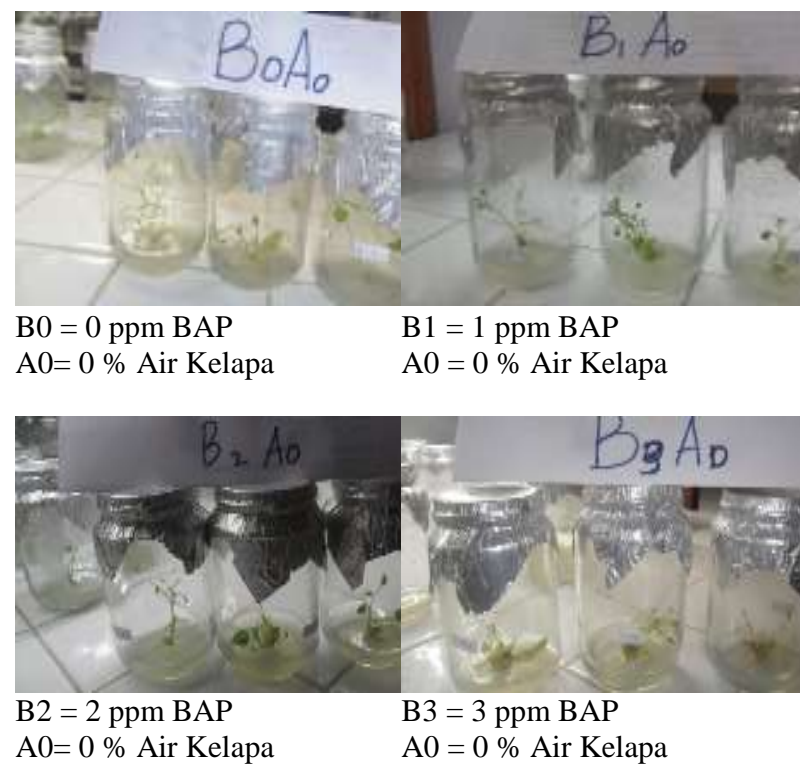

Gambar 1. Jumlah Daun Umur 4 MSK (minggu setelah kultur)

Rata-rata jumlah daun umur 4 MSK menunjukkan perlakuan BAP 3 ppm memiliki rerata tertinggi yaitu 6.38 helai, ini menunjukkan BAP dapat memberikan pengaruh pada jumlah daun meski perlakuan BAP 3 ppm tidak berbeda dengan perlakuan BAP $0 \mathrm{ppm}$ dan BAP $1 \mathrm{ppm}$ namun berbeda dengan perlakuan BAP $2 \mathrm{ppm}$ yaitu 3.25 helai (Tabel 2 dan Gambar 1). Fithriyandini, Maghfoer \& Wardiyati, (2015) mendapatkan bahwa penggunaan BAP 2,5 ppm + $1 / 2$ MS pada tanaman angrek dapat menghasilkan daun sebanyak 6 helai pada 12 MSK. Pada penelitian lainnya oleh Talukder et al, (2003) melaporkan bahwa pemberian BAP 2,5 mg/l air menghasilkan jumlah daun tertinggi yaitu 2,55 helai pada anggrek. Penggunaan ZPT dalam kultur in vitro pada batas-batas tertentu mampu merangsang pertumbuhan, namun dapat bersifat penghambat apabila digunakan melebihi konsentrasi optimum (George \& Sherrington, 1984).

Pengaruh air kelapa terhadap jumlah daun umur 6 minggu setelah kultur menunjukan tidak berpengaruh nyata (Tabel 3 dan Gambar 2).

Tabel 3. Pengaruh Air Kelapa Terhadap Jumlah Daun Umur 6 MSK (minggu setelah kultur)

\begin{tabular}{ll}
\hline Perlakuan & Rata-rata Jumlah Daun \\
\hline Air Kelapa (\%) & \\
\hline A0 (0) & $13.13^{\mathrm{a}}$ \\
A20 (20) & $21.31^{\mathrm{a}}$ \\
\hline BNT 5\% & 10.77 \\
\hline
\end{tabular}

Keterangan: Angka yang diikuti dengan huruf yang sama, tidak berbeda nyata berdasarkan uji BNT $5 \%$.

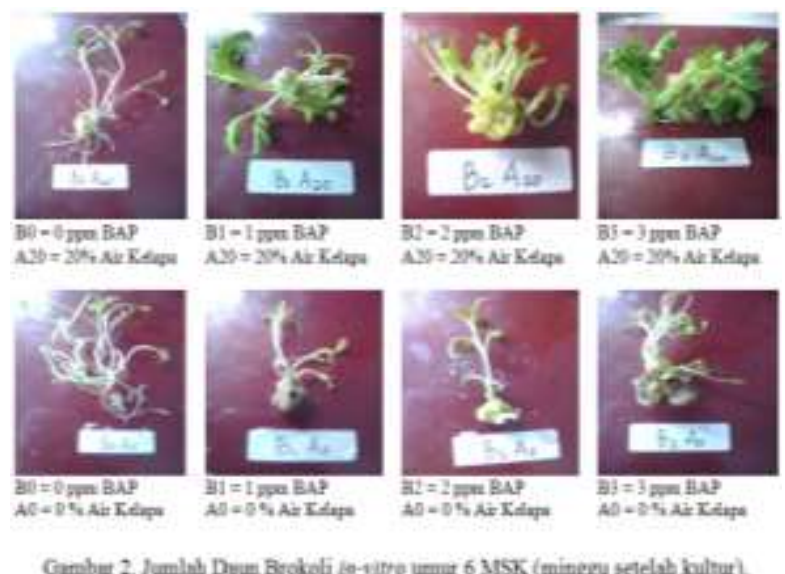

Tabel 3 dan Gambar 2, rata-rata jumlah daun terbanyak pada perlakuan air kelapa dengan konsentrasi $20 \%$ yaitu 21.31 ini menunjukan bahwa air kelapa cenderung memperbanyak jumlah daun. Hal ini di buktikan oleh Astutik (2008) mendapatkan dengan penambahan air kelapa sebesar 7.5\% mampu mendapatkan jumlah daun pisang ambon terbanyak yaitu 6.90. Sulistiyorini, Maynarti \& Syafaruddin (2012) menyatakan penambahan $20 \%$ air kelapa pada tanaman lada mampu mendapatkan rerata jumlah 
daun tertinggi yaitu 7.20. Hal ini disebabkan karena penambahan air kepala sampai $40 \%$ mampu meningkatkan tinggi tanaman dan jumlah tunas tanaman krisan (Mandang, 1993). Selanjutnya Wattimena (1988) menyatakan bahwa air kelapa mengandung zat aktif untuk perkembangan embrio seperti sitokinin, sitokinin mempengaruhi metabolisme asam nukleat dan sintesa protein yang berpengaruh terhadap pembelahan sel dan diferensiasi tanaman.

Rata -rata jumlah daun dari perlakuan kombinasi BAP dan Air Kelapa umur 2 minggu setelah tanam disajikan pada Tabel 4 dan bisa di lihat pada Gambar 3.

Tabel 4. Pengaruh Kombinasi BAP dengan Air Kelapa Terhadap Jumlah Daun Umur 2 MSK

\begin{tabular}{|c|c|c|c|c|c|}
\hline \multirow[t]{2}{*}{$\operatorname{AK}(\%)$} & \multicolumn{4}{|c|}{ BAP (mg/l) } & \multirow[t]{2}{*}{ Rata-rata } \\
\hline & 0 & 1 & 2 & 3 & \\
\hline 0 & $2.50^{\mathrm{ab}}$ & $1.75^{\mathrm{ab}}$ & $2.50^{\mathrm{ab}}$ & $1.25^{\mathrm{a}}$ & 2.00 \\
\hline 20 & $2.75^{b}$ & $1.25^{\mathrm{a}}$ & $1.50^{\mathrm{a}}$ & $2.50^{\mathrm{ab}}$ & 2.00 \\
\hline Rata-rata & 2.63 & 1.50 & 2.00 & 1.88 & \\
\hline BNT 5\% & 1.15 & & & & \\
\hline
\end{tabular}

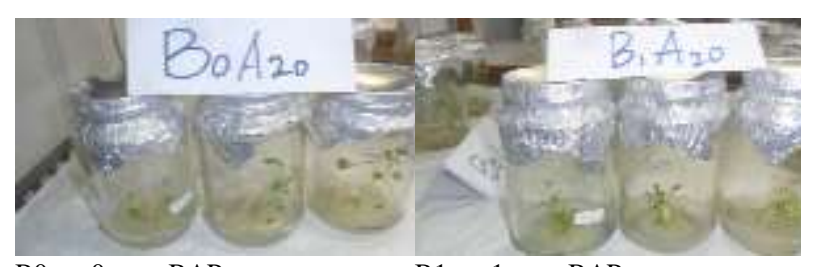

B0 $=0$ ppm BAP $\mathrm{A} 20=20 \%$ Air Kelapa

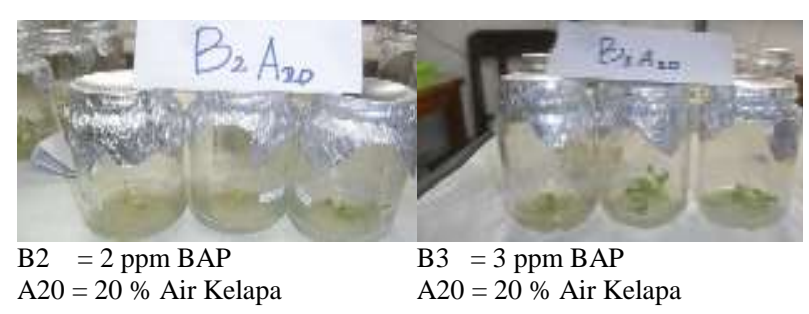

Gambar 3. Jumlah Daun in vitro umur 2 MSK.

Tabel 4 dan Gambar 3 menunjukkan bahwa rerata jumlah daun terbanyak pada perlakuan kombinasi 0 ppm BAP dan $20 \%$ air kelapa yaitu 2.75, meskipun perlakuan ini tidak berbeda dengan perlakuan $0 \%$ air kelapa +0 ppm BAP, 0 $\%$ air kelapa +1 ppm BAP, $0 \%$ Air Kelapa +2 ppm BAP dan $20 \%$ Air Kelapa +3 ppm BAP, namun air kelapa cenderung dapat meningkatkan jumlah daun. Menurut Bulago, Akannde \& Ogunbodede (2007) bahwa penggunaan BAP dengan konsentrasi $1.5 \mathrm{mg} / \mathrm{l}$ dilaporkan mampu menghasilkan jumlah daun tertinggi pada tanaman Telfairia occidentalis Hook. Penggunaan BAP 3 $\mathrm{ppm} / \mathrm{l}$ menghasilkan jumlah daun terbanyak tanaman Anggrek (Dendrobium sp) dengan ratarata 9.81 jumlah daun per tunas (Meklin \& dkk, 2015).

Amutha et al (2003) menyatakan bahwa penggunaan Air Kelapa pada konsentrasi $10 \%$ dapat merangsang pembentukan tunas pada 4 var. tanaman kacang hijau, sehingga secara tidak langsung perlakuan yang digunakan dapat meningkatkan jumlah daun yang terbentuk dikarenakan Air Kelapa memiliki unsur K tinggi diikuti $\mathrm{Na}, \mathrm{Mg}$ dan unsur-unsur lainnya. Proses pembentukan daun dalam kultur in vitro dengan penggunaan Air Kelapa berkaitan dengan keberadaan unsur $\mathrm{K}$ dan $\mathrm{Mg}$ yang relatif tinggi pada media yang digunakan. Berdasarkan komposisi mineral dan hormon yang terkandung pada Air Kelapa maka diduga pemberian Air Kelapa dapat memberikan pengaruh yang baik terhadap rata-rata jumlah daun per eksplan.

\section{Jumlah Tunas}

Dari hasil analisis ragam didapatkan bahwa BAP 3 ppm dapat memberikan pengaruh nyata pada umur 2 dan 6 MSK (minggu setelah kultur). Rata-rata jumlah tunas dari perlakuan BAP umur 2 dan 6 MSK disajikan pada Tabel 5 dan Gambar 4 dan 5 .

Tabel 5. Pengaruh BAP Terhadap Jumlah Tunas Umur 2

\begin{tabular}{lcc}
\multicolumn{3}{c}{ dan 6 MSK } \\
\hline Perlakuan & \multicolumn{2}{c}{ Rata-rata Jumlah Tunas (MSK) } \\
\hline BAP $(\mathrm{mg} / \mathrm{l})$ & 2 & 6 \\
\hline B0 $(0 \mathrm{ppm})$ & $1.00^{\mathrm{a}}$ & $6.13^{\mathrm{a}}$ \\
B1 (1 ppm) & $1.38^{\mathrm{a}}$ & $7.88^{\mathrm{a}}$ \\
B2 (2 ppm) & $1.25^{\mathrm{a}}$ & $8.38^{\mathrm{ab}}$ \\
B3 (3 ppm) & $2.75^{\mathrm{b}}$ & $12.13^{\mathrm{b}}$ \\
\hline BNT 5\% & 1.16 & 4.16 \\
\hline
\end{tabular}

Keterangan: Angka yang diikuti dengan huruf yang sama, tidak berbeda nyata berdasarkan uji BNT $5 \%$.
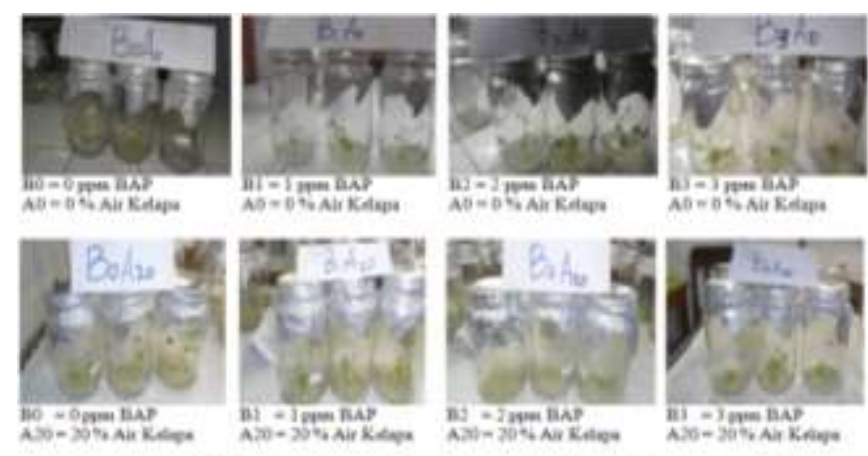

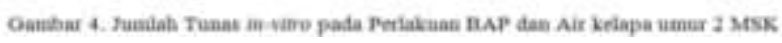



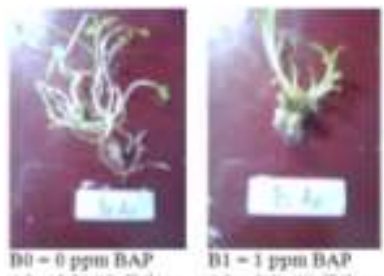

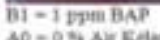

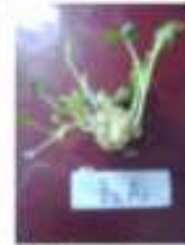

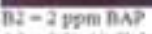

A0 0 - 5 Air Kolej,

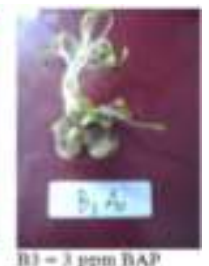

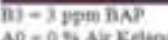

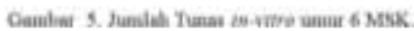

Tabel 5 dan Gambar 4 serta Gambar 5, menunjukkan bahwa perlakuan BAP $3 \mathrm{ppm}$ memberikan pengaruh nyata pada umur 2 dengan rerata jumlah tunas tertinggi yaitu 2.75. Pada umur 6 MSK perlakuan BAP 3 ppm berbeda nyata dengan perlakuan B0 (0 ppm), B1 (1 ppm) namun tidak berbeda dengan perlakuan B2 (2 ppm).

Sebagaimana Tilaar, (2012) mendapatkan rata-rata jumlah tunas terbanyak pada tanaman brokoli dengan konsentrasi 2.5 ppm BAP yaitu 17 tunas. Penelitian lainnya yang dilakukan oleh Alsaif, Hossain \& Taha (2011) mendapatkan konsentrasi BAP $2 \mathrm{mg} / \mathrm{l}$ merupakan konsentrasi efektif untuk pertumbuhan dan perkembangan tunas nenas. Pada tanaman tembakau, Nisak, Nurhidayati \& Purwanin (2012) mendapatkan konsentrasi BAP 4 ppm +0.1 ppm NAA memiliki rerata tertinggi yaitu 52.5 tunas, hal ini menunjukan bahwa BAP sebagai sitokinin sangat efektif untuk menginisiasi tunas secara langsung maupun tidak langsung. Kombinasi IAA $0.1 \mathrm{ppm}$ + BAP 3 ppm menghasilkan rerata jumlah tunas terbanyak yaitu 8 tunas pada tanaman kentang secara in-vitro (Septiana, Slameto \& Restanto, 2014).

Dari hasil-hasil penelitian tersebut diatas dapat dikatakan bahwa BAP dapat meningkatkan jumlah tunas. Hal ini dikarenakan berkaitan dengan fungsi fisiologis sitokinin dapat merangsang pembelahan sel dan peran sitokinin dalam morfogenesis adalah dalam pembentukan tunas (Hess dalam Tilaar, 2016).

Rata-rata jumlah tunas dari perlakuan air kelapa umur 6 MSK disajikan pada Tabel 6 dan Gambar 6.

Tabel 6. Pengaruh Air Kelapa Terhadap Jumlah Tunas Umur 6 MSK

\begin{tabular}{lc}
\hline Perlakuan & Rata-rata Jumlah Tunas \\
\hline Air Kelapa (\%) & \\
\hline A0 (0) & $6.44^{\mathrm{a}}$ \\
A20 (20) & $10.81^{\mathrm{b}}$ \\
\hline BNT 5\% & 4.16 \\
\hline Keterangan: & $\begin{array}{c}\text { Angka yang diikuti dengan huruf yang sama, } \\
\text { tidak berbeda nyata berdasarkan uji BNT 5\%. }\end{array}$
\end{tabular}

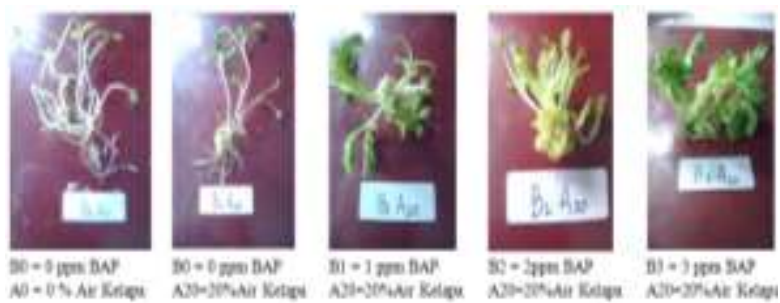

Gamber 6. Pertakuan kombinasi BAP dan Air Krlapa umar 6 MSK

Tabel 6 dan Gambar 6, menunjukkan bahwa perlakuan air kelapa memberikan pengaruh nyata pada jumlah tunas umur 6 MSK dengan rerata jumlah tunas 10.81 dan berbeda nyata dengan perlakuan tanpa air kelapa. Mandang, 1997 mendapatkan pada penambahan air kelapa hingga $45 \%$ mampu meningkatkan jumlah tunas tanaman krisan sebesar 10.2 tunas /eksplan. Hal ini menunjukkan bahwa penambahan air kelapa dapat meningkatkan jumlah tunas. Rata-rata jumlah tunas dari perlakuan kombinasi BAP dengan air kelapa disajikan pada Tabel 7 dan Gambar 7.

Tabel 7. Pengaruh Kombinasi BAP dengan Air Kelapa Terhadap Jumlah tunas Umur 2 MSK

\begin{tabular}{cccccc}
\hline AK (\%) & \multicolumn{4}{c}{ BAP (mg/l) } & Rata-rata \\
\hline & 0 & 1 & 2 & 3 & \\
\hline 0 & $1.00^{\mathrm{a}}$ & $1.75^{\mathrm{ab}}$ & $1.25^{\mathrm{a}}$ & $2.50^{\mathrm{bc}}$ & 1.63 \\
20 & $1.00^{\mathrm{a}}$ & $1.00^{\mathrm{a}}$ & $1.25^{\mathrm{a}}$ & $3.00^{\mathrm{c}}$ & 1.56 \\
\hline Rata-rata & 1.00 & 1.38 & 1.25 & 2.75 & \\
\hline
\end{tabular}

\section{BNT 5\% 1.16}

Keterangan: Angka yang diikuti dengan huruf yang sama, tidak berbeda nyata berdasarkan uji BNT $5 \%$.

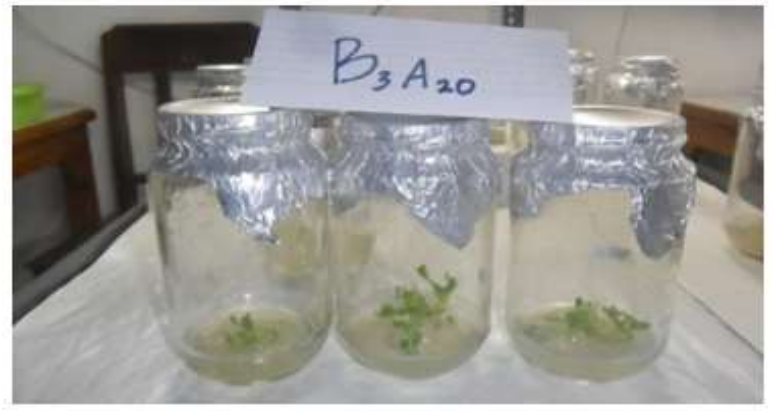

Gambar 7. Jumlah Tunas in-vitro umur 2 MSK

Tabel 7 dan Gambar 7, menunjukkan bahwa nilai rerata tertinggi jumlah tunas pada pengamatan umur 2 MSK terdapat pada perlakuan kombinasi 3 ppm BAP dan 20\% Air Kelapa yaitu 3.00 berbeda nyata dengan 0 ppm BAP + Air Kelapa $20 \%, 1$ ppm BAP + Air Kelapa $20 \%$ dan 2 ppm BAP + Air Kelapa 20 
$\%, 0$ ppm BAP $+0 \%$ Air Kelapa, 1 ppm BAP $+0 \%$ Air Kelapa dan 2 ppm BAP $+0 \%$ Air Kelapa namun tidak berbeda dengan 3 ppm $\mathrm{BAP}+0 \%$ Air Kelapa. Ini menunjukkan bahwa air kelapa cenderung meningkatkan jumlah tunas meski tidak berbeda dengan perlakuan 3 ppm BAP tanpa penambahan air kelapa.

Menurut Suminar dkk (2017) konsentrasi BAP $1.5 \mathrm{mg} / \mathrm{l}$ merupakan perlakuan terbaik pada multiplikasi eksplan embrionik axis kedelai var. Mutiara I secara in vitro. Wattimena dkk (1988) meyebutkan bahwa difenilurea yang terkandung dalam Air Kelapa memiliki aktivitas sama seperti sitokinin, sehingga dalam penggunaannya Air Kelapa mampu merangsang pembentukan tunas dengan nilai tertinggi namun tidak berbeda nyata dengan perlakuan yang menggunakan sitokinin sintetik. Air kelapa yang disubtitusi pada media kultur akan meningkatkan pertumbuhan tunas tanaman krisan dan anggrek (Mandang et al (1997) dan Matatula (2003). Air kelapa pada media kultur jaringan memperbaiki pertumbuhan tunas, medorong pertumbuhan kalus dan morfogenisis (Wattimena, PoliiMandang \& Purwito, 1990).

\section{Tinggi Tunas}

Data dan analisis ragam tinggi tunas dapat dilihat pada Lampiran 3. Berdasarkan analisis ragam tinggi tunas menunjukkan bahwa perlakuan BAP memberikan pengaruh nyata terhadap tinggi tunas sedangkan perlakuan air kelapa dan perlakuan kombinasi BAP dengan air kelapa tidak memberikan pengaruh nyata terhadap tinggi tunas. Rata-rata tinggi tunas dari perlakuan BAP disajikan pada Tabel 8 dan Gambar 8 .

Tabel 8. Pengaruh BAP Terhadap Tinggi Tunas dan Berat Basah

\begin{tabular}{lcc}
\hline Perlakuan & $\begin{array}{c}\text { Rata-rata Tinggi } \\
\text { Tunas (cm) }\end{array}$ & $\begin{array}{c}\text { Rata-rata } \\
\text { Berat Basah (g) }\end{array}$ \\
\hline BAP (mg/l) & & $0.736^{\mathrm{a}}$ \\
\hline B0 (0 ppm) & $9.88^{\mathrm{b}}$ & $1.024^{\mathrm{a}}$ \\
B1 (1 ppm) & $4.04^{\mathrm{a}}$ & $1.175^{\mathrm{a}}$ \\
B2 (2 ppm) & $3.75^{\mathrm{a}}$ & $2.479^{\mathrm{b}}$ \\
B3 (3 ppm) & $4.90^{\mathrm{a}}$ & 1.19 \\
\hline BNT 5\% & 2.90 & Angka yang diikuti dengan huruf yang sama, \\
\hline Keterangan: & $\begin{array}{l}\text { Aidak berbeda nyata berdasarkan uji BNT } \\
\text { 5\%. }\end{array}$
\end{tabular}

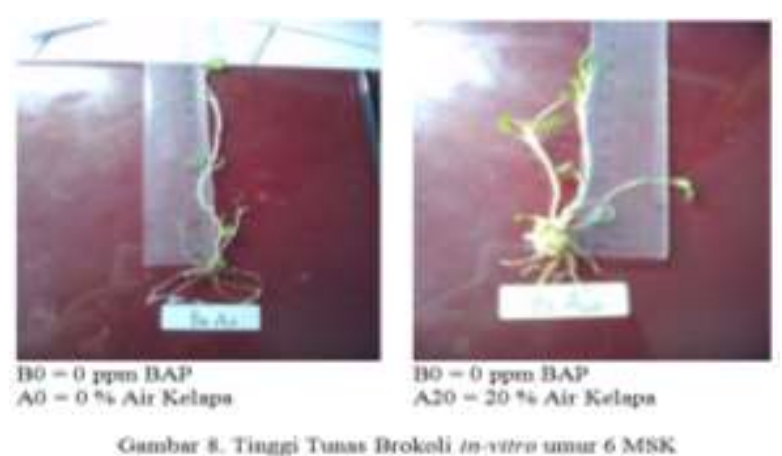

Tabel 8 dan Gambar 8, menunjukkan bahwa tinggi tunas tertinggi pada perlakuan 0 ppm BAP berbeda nyata dengan perlakuan B1 (1 ppm BAP), B2 (2 ppm BAP), dan B3 (3 ppm BAP). Namun tanaman pada perlakuan $0 \mathrm{ppm}$ BAP menunjukan pertumbuhan yang kurang vigor karena tanaman nampak seperti etiolasi. Pengaruh BAP yang terjadi setelah di analisis Tilaar, (2012) juga mendapatkan konsentrasi 0 ppm NAA +0 ppm BAP menghasilkan rerata tinggi tunas yang terbaik yaitu 6.50 pada tanaman Brokoli. Menurut Hess dalam Tilaar (2012) menyatakan bahwa fungsi sitokinin seperti BAP hanya untuk pembelahan sel, sehingga BAP menekan tinggi tunas dan secara morfogenesis BAP berperan pada pembentukan tunas karena adanya fungsi tersebut menunjukan bahwa penambahan BAP tidak berpengaruh pada tinggi tanaman.

Hal ini menunjukan bahwa salah satu faktor tanaman tidak dapat mengendalikan lagi pertumbuhan tingginya ialah dengan pemberian ZPT, menurut Heti, dkk (2015) bahwah hasil uji BNT dengan kombinasi NAA dan BAP pada taraf NAA $5 \mu \mathrm{m}$ dan BAP $0 \mu \mathrm{m}$ menunjukan tinggi tunas yang baik yaitu sebesar $1.20 \mathrm{~cm}$ dan ini tidak berbeda dengan pemberian NAA $0 \mu \mathrm{m}$ dan BAP $18 \mu \mathrm{m}$ yaitu $1.13 \mathrm{~cm}$ pada tanaman Nepenthe ampullaria Jack, ini membuktikan bahwa untuk menghasilkan tanaman yang cukup tingi hanya diperlukan NAA yang rendah tanpa perlu menggunakan BAP. Tabel 8 dan Gambar 8 menunjukkan bahwa tinggi tunas tertinggi pada perlakuan 0 ppm BAP berbeda nyata dengan perlakuan B1 (1 ppm BAP), B2 (2 ppm BAP), dan B3 (3 ppm BAP). Namun tanaman pada perlakuan 0 ppm BAP menunjukan pertumbuhan yang kurang vigor karena tanaman nampak seperti etiolasi. Pengaruh BAP yang terjadi setelah di analisis Tilaar, (2012) juga mendapatkan konsentrasi 0 ppm NAA +0 ppm BAP menghasilkan rerata tinggi tunas yang terbaik 
yaitu 6.50 pada tanaman Brokoli. Menurut Hess dalam Tilaar (2012) menyatakan bahwa fungsi sitokinin seperti BAP hanya untuk pembelahan sel, sehingga BAP menekan tinggi tunas dan secara morfogenesis BAP berperan pada pembentukan tunas karena adanya fungsi tersebut menunjukan bahwa penambahan BAP tidak berpengaruh pada tinggi tanaman.

Hal ini menunjukan bahwa salah satu faktor tanaman tidak dapat mengendalikan lagi pertumbuhan tingginya ialah dengan pemberian ZPT, menurut Heti, dkk (2015) bahwah hasil uji BNT dengan kombinasi NAA dan BAP pada taraf NAA $5 \mu \mathrm{m}$ dan BAP $0 \mu \mathrm{m}$ menunjukan tinggi tunas yang baik yaitu sebesar $1.20 \mathrm{~cm}$ dan ini tidak berbeda dengan pemberian NAA 0 $\mu \mathrm{m}$ dan BAP $18 \mu \mathrm{m}$ yaitu $1.13 \mathrm{~cm}$ pada tanaman Nepenthe ampullaria Jack, ini membuktikan bahwa untuk menghasilkan tanaman yang cukup tingi hanya diperlukan NAA yang rendah tanpa perlu menggunakan BAP.

\section{Berat Basah}

Analisis ragam berat basah menunjukkan bahwa perlakuan BAP memberikan pengaruh nyata terhadap berat basah, sedangkan perlakuan air kelapa dan perlakuan kombinasi BAP dengan air kelapa tidak memberikan pengaruh nyata terhadap berat basah. Rata-rata berat basah dari perlakuan BAP disajikan pada Tabel 8. Tabel 8 menunjukkan bahwa berat basah tertinggi pada perlakuan 3 ppm BAP dan berbeda nyata dengan perlakuan B0 (0 ppm BAP), B1 (1 ppm BAP) dan B2 (2 ppm BAP). Hasil yang didapatkan berat basah tidak selaras dengan tinggi tanaman (Tab.8), tanpa BAP tanaman tinggi namun perlakuan BAP dan Air Kelapa tanaman pendek dan memiliki berat basah paling rendah. Hal ini disebabkan karena tanaman tersebut tinggi namun tidak vigor.

Auksin dalam konsentrasi rendah dan dikombinasikan dengan sitokinin dalam konsentrasi tertentu mampu mempercepat perpanjangan tunas (Klerk, 2006). Auksin menstimulasi pembesaran dan perpanjangn sel setelah terjadi pembelahan sel yang distimulir oleh sitokinin. Septiana, Slameto \& Restanto, (2014) kombinasi IAA 0,1 ppm dan BAP 3 ppm menghasilkan rerata tinggi tunas yaitu $10,9 \mathrm{~cm}$ pada nodus tangkai bunga anggrek bulan (Phalaenoosis amabilis). Pemberian konsentrasi BAP yang tinggi tidak dapat meningkatkan tinggi planlet, ini disebabkan karena BAP adalah sitokinin yang dapat mendorong pembelahan sel, membantu perkembangan embrio seara teratur pada perkecambahan biji, menghambat degradasi klorofil dan menghambat penuaan (Noggle \& Fritz, 1977).

\section{Jumlah Akar}

Analisis ragam jumlah akar menunjukkan bahwa perlakuan BAP memberikan pengaruh nyata terhadap jumlah akar, sedangkan perlakuan air kelapa dan perlakuan kombinasi BAP dengan air kelapa tidak memberikan pengaruh nyata terhadap jumlah akar. Rata-rata jumlah akar dari perlakuan BAP disajikan pada Tabel 9 dan Gambar 9.

Tabel 9. Pengaruh BAP Terhadap Jumlah Akar

\begin{tabular}{lc}
\hline Perlakuan & Rata-rata Jumlah Akar \\
\hline BAP $(\mathrm{mg} / \mathrm{l})$ & \\
\hline B0 $(0 \mathrm{ppm})$ & $7.75^{\mathrm{b}}$ \\
B1 (1 ppm) & $0.00^{\mathrm{a}}$ \\
B2 (2 ppm) & $0.13^{\mathrm{a}}$ \\
B3 (3 ppm) & $0.00^{\mathrm{a}}$ \\
\hline BNT 5\% & 1.27 \\
\hline
\end{tabular}

Keterangan: Angka yang diikuti dengan huruf yang sama, tidak berbeda nyata berdasarkan uji BNT 5\%

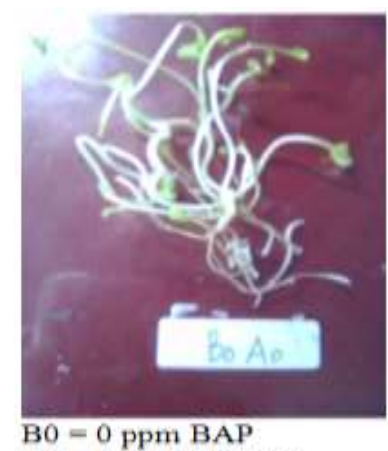
AO $=0 \%$ Air Kelapa

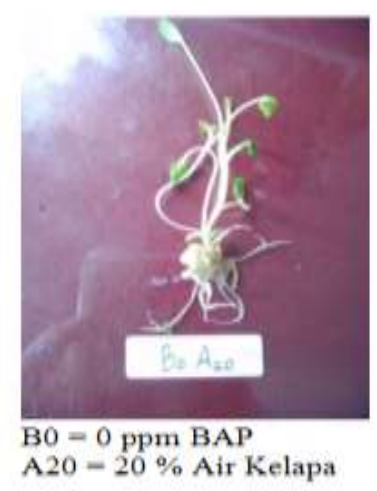

Gambar 9, Perlakuan BAP 0 ppm + Air kelapa 0\% dan BAP $0 \mathrm{ppm}+20 \%$ Air kelapa umur $6 \mathrm{MSK}$

Tabel 9 dan Gambar 9, menunjukkan bahwa jumlah akar terbanyak pada perlakuan 0 ppm BAP dan berbeda nyata dengan perlakuan B1 (1 ppm BAP), B2 (2 ppm BAP) dan B3 (3 ppm BAP). Penggunaan BAP sebagai sitokinin pada dasarnya berfungsi untuk memicu pecahnya seludang tunas dan tumbuhan mata tunas, selain itu BAP akan mencegah dominansi 
apikal sehingga pertumbuhan tunas samping tidak terhambat (Salisbury dan Roos, 1992). BAP memiliki sifat yang sangat aktif yang berperan dalam diferensiasi sel, memicu pertumbuhan tunas, proliferasi tunas ketiak dan justru menghabat pembentukan akar (Wattimena, 1988).

Pertumbuhan akar terjadi pada saat tanaman telah berkembang lengkap sehingga auksin endogen yang berperan dalam pembentukan akar telah tersintesis pada pembentukan pucuk dan terakumulasi pada daerah pangkal tunas. Auksin endogen dibentuk pada pucuk yaitu IAA dan turun ke dasar tanaman sehingga akan merangsang perakaran, selain itu auksin berfungsi untuk merangsan pembesaran dan pemanjangan sel dan merangsan pembentukan akar (Hess dalam Tilaar, 2012). Isda \& Fatonah, (2014) mendapatkan rerata jumlah akar terbanyak pada eksplan anggrek sebanyak 5 buah dengan konsentrasi kombinasi BAP 0,5 ppm dan NAA 0,5 ppm. Mukhtar et al (2005) menyatakan bahwa pemberian $2 \mathrm{mg} / \mathrm{l}$ NAA dapat memberikan hasil terbaik terhadap panjang akar Citrus reticulate, hal ini menunjukan bahwa konsentrasi NAA yang optimum dalam induksi dan pemanjangan akar setiap taman berbeda-beda dan dipengaruhi keseimbangan antara hormon endogen (IAA) dan hormon eksogen. Tabel 9 dan Gambar 9, menunjukkan bahwa jumlah akar terbanyak pada perlakuan 0 ppm BAP dan berbeda nyata dengan perlakuan $\mathrm{B} 1$ (1 ppm BAP), B2 (2 ppm BAP) dan B3 (3 ppm BAP). Penggunaan BAP sebagai sitokinin pada dasarnya berfungsi untuk memicu pecahnya seludang tunas dan tumbuhan mata tunas, selain itu BAP akan mencegah dominansi apikal sehingga pertumbuhan tunas samping tidak terhambat (Salisbury dan Roos, 1992). BAP memiliki sifat yang sangat aktif yang berperan dalam diferensiasi sel, memicu pertumbuhan tunas, proliferasi tunas ketiak dan justru menghabat pembentukan akar (Wattimena, 1988).

Pertumbuhan akar terjadi pada saat tanaman telah berkembang lengkap sehingga auksin endogen yang berperan dalam pembentukan akar telah tersintesis pada pembentukan pucuk dan terakumulasi pada daerah pangkal tunas. Auksin endogen dibentuk pada pucuk yaitu IAA dan turun ke dasar tanaman sehingga akan merangsang perakaran, selain itu auksin berfungsi untuk merangsan pembesaran dan pemanjangan sel dan merangsan pembentukan akar (Hess dalam Tilaar, 2012). Isda \& Fatonah, (2014) mendapatkan rerata jumlah akar terbanyak pada eksplan anggrek sebanyak 5 buah dengan konsentrasi kombinasi BAP 0,5 ppm dan NAA 0,5 ppm. Mukhtar et al (2005) menyatakan bahwa pemberian $2 \mathrm{mg} / \mathrm{l}$ NAA dapat memberikan hasil terbaik terhadap panjang akar Citrus reticulate, hal ini menunjukan bahwa konsentrasi NAA yang optimum dalam induksi dan pemanjangan akar setiap taman berbeda-beda dan dipengaruhi keseimbangan antara hormon endogen (IAA) dan hormon eksogen.

\section{Kandungan Sulforafan}

Analisis kandungan sulforafan menunjukkan ke delapan perlakuan yang di berikan pada tanaman brokoli tidak terdeteksi kandungan sulforafan. Ada berbagai macam kendala yang terjadi pada keadaan ini, adanya hal-hal menyangkut faktor eksternal maupun faktor internalnya. Faktor eksternal meliputi : cahaya dan suhu, dan faktor internalnya meliputi : faktor pemberian ZPT, sumber karbon, derajat keasaman, prasat (precursor), imobilisasi sel dan elisitasi. Faktor eksternal dan faktor internal adalah sebagai berikut:

\section{Faktor eksternal}

Cahaya merupakan faktor penentu dalam peningkatan kandungan metabolik sekunder dikarenakan adanya fotoperioditas. Masing-masing tanaman memiliki respon yang berbeda terhadap cahaya, contoh nyata pada kultur kalus Haplopappus gracillis lebih tinggi jika kultur berada dalam gelap selama 3 hari sebelum didedahkan pada cahaya dibandingkan jika kultur berada dalam gelap selama 1 hari sebelum didedahkan pada cahaya (Mantell \& Smith, 1983). Pada penelitian Kurata, dkk (1999) dan Sartor \& Mazzafera (2000) mendapatkan pada kultur sel kopi arabika dengan melakukan stress intensitas cahaya yang tinggi maka terjadi peningkatan kandungan kafein pada sel-sel kopi.

Kandungan metabolik sekunder dipengaruhi juga oleh suhu. Kumar et al (2012) mendapatkan perlakuan suhu pada kultur kalus Heliotropium indicum L pada 
media MS dengan perlakuan suhu $25^{\circ} \mathrm{C}$ memiliki kandungan flavonoid tertinggi $(1,67$ $\pm 0.04 \mathrm{mg} / \mathrm{g}$ ). Zhong \& Yoshida (2003) menyatakan bahwa produksi anthocyanin dapat berkurang pada temperatur lebih tinggi dari $28^{\circ} \mathrm{C}$ dan optimal pada $25^{\circ} \mathrm{C}$. Kandungan nikotin pada kultur kalus tembakau pada suhu $27^{\circ} \mathrm{C}$ meningkat 100-200 \% (Mantell \& Smith, 1983). Hal ini menunjukan bahwa suhu juga berpengaruh pada metabolik sekunder namun respons suhu pada setiap tanaman berbeda-beda.

2. Faktor internal

Zat pengatur tumbuh pada macam dan konsentrasi yang tepat dapat memacun sintesis metabolik sekunder. Mantell \& Smith, 1983 mendapatkan bahwa penambahan konsentrasi kinetin yang tinggi pada medium akan menghambat sintesis alkaloid pada tanaman Datura tatula, sedangkan pada tanaman Scopolia maxima konsentrasi kinetin yang tinggi justru dapat memacu sintesis alkaloid. Konsentrasi kinetin mg/l dan 2,4-D $\mathrm{mg} / \mathrm{l}$ semakin tinggi maka semakin tinggi pula kandungan saponin pada tanaman Talinum peniculatum Gaert.

Nutrisi dalam medium kultur jaringan tumbuhan mempengaruhi metabolisme primer dan sekunder sel (Misawa, 1994), lanjutnya konsetrasi fosfat dapat meningkatkan kandungan indol alkaloid pada kultu C.roseus, dalam kultur sel Rosa sp kandungan senyawa fenolik menurun jika konsentrasi nitrogen organik dalam medium ditingkatkan. Pada tanaman tembakau penambahan $50 \mathrm{~g} / \mathrm{l}$ sukrosa meningkatkan kandungan nikotin dalam sel tembakau dibandingkan dengan 20 g/l sukrosa. Derajat keasaman dapat mempengaruhi metabolit sekunder pada kultur jaringan, pada kultur sel Ipomea $s p$ pada penambahan triptofan dalam medium $\mathrm{pH}$ 6,3 dapat menghasilkan triptofan dua kali lipat leibh tinggi dibandingkan dengan triptofan yang dihasilkan pada medium $\mathrm{pH}$ 4,8 (Mantell \& Smith, 1983).
Penambahan prazat (precursor) dalam kultur jaringan dapat meningkatkan metabolik sekunder, dalam kultur kalus Dioscorea deltoidea ditambahkan 100 ppm kolesterol dapat meningkatkan produksi diosgenin hingga $100 \%$ (Chowdhury \& Chaturvedi, 1980). Pemberian prazat metionin 10 ppm dan ekstrak benih brokoli $3 \mathrm{~g} / \mathrm{l}$ pada tanaman brokoli mampuh mening-katkan kandungan sulforafan (Rumondor, Polii-Mandang \& Rotinsulu, 2013). Tanaman tapak darah dengan penambahan triptofan 50 sampai $250 \mathrm{mg} / \mathrm{l}$ dapat meningkatkan kandungan katarantin dalam kultur tapak darah (Pandiangan dkk, 2011).

\section{KESIMPULAN DAN SARAN}

\section{Kesimpulan}

Berdasarkan hasil penelitian, didapatkan penggunaan konsentrasi BAP 3 ppm cenderung meningkatkan jumlah daun umur 4 (MSK) minggu setelah kultur dan meningkatkan jumlah tunas umur 2 dan 6 (MSK) minggu setelah kultur. BAP 3 ppm dapat meningkatkan berat basah umur 6 (MSK). Air kelapa $20 \%$ cenderung meningkat-kan jumlah daun pada umur 6 (MSK) minggu setelah kultur dan meningkatkan jumlah tunas umur 6 MSK, sedangkan untuk kombinasi 3 ppm BAP dan air kelapa $20 \%$ cenderung meningkat-kan jumlah daun umur 2 MSK dan jumlah tunas umur 2 MSK. Pemberian kombinasi air kelapa dan BAP tidak terdeteksi kandungan suforafan Berdasarkan hasil penelitian, didapatkan penggunaan konsentrasi BAP $3 \mathrm{ppm}$ cenderung meningkatkan jumlah daun umur 4 (MSK) minggu setelah kultur dan meningkatkan jumlah tunas umur 2 dan 6 (MSK) minggu setelah kultur. BAP 3 ppm dapat meningkatkan berat basah umur 6 (MSK). Air kelapa $20 \%$ cenderung meningkat-kan jumlah daun pada umur 6 (MSK) minggu setelah kultur dan meningkatkan jumlah tunas umur 6 MSK, sedangkan untuk kombinasi 3 ppm BAP dan air kelapa $20 \%$ cenderung meningkat-kan jumlah daun umur 2 MSK dan jumlah tunas umur 2 MSK. Pemberian kombinasi air kelapa dan BAP tidak terdeteksi kandungan suforafan. 


\section{Saran}

1. Gunakanlah Air Kelapa sebagai bahan subtitusi media dan sebagai bahan alternatif yang mudah di dapatkan dan harganya murah

2. Bisa menggunakan konsentrasi air kelapa lebih dari $20 \%$ sehingga menghemat pemakaian zat pengatur tumbuh sintetik.

3. Diharapkan melalui penelitian ini bisa menjadi referensi untuk penelitian selanjutnya.

\section{DAFTAR PUSTAKA}

(1993). Peran Air Kelapa dalam Kultur Jaringan Tanaman Krisan. Disertasi. Istitut Pertanian Bogor.

(1995). Air Kelapa Sebagai

Bahan Subtitusi Media MS pada Kultur Jaringan Krisan. Eugenia 1(1) : $1-11$

Apriadji, W. H. (2008). Menimbang Keunggulan Sayuran Daun. Retrieved Maret 7, 2017, from multiply: http://kulinerkita.muliply. com/reviews/items/506

Bey, Y., Syafii, W., \& Sutrisna. (2006). Pengaruh Pemberian Giberalin (GA3) dan air kelapa terhadap perkecambahan biji anggrek bulan (Phalaenopsis amabilis BL) secara in vitro. j. Biogenesis 2 (2), 41-46.

Chowdhury, A. R., \& Chaturvedi, H. C. (1980). Cholesterol and Bioshynthesis of diosgenin by tuber callus of Dioscore deltoidea. Curren Science, (49) : 237-8.
Fithriyandini, A., Maghfoer, D. M., \& Wardiyati, T. (2015). Pengaruh Media Dasar dan 6-Benzylaminopurine (BAP) terhadap Pertumbuhan dan Perkembangan Nodus Tangkai Bunga Anggerk Bulan (Phalaenopsis amabilis) dalam perbanyakan secara in vitro.

George, E. F., \& Sherrington, P. D. (1984). Plant Propagation by Tissue Culture. England: Exegetics Limited.

Isda, N. M., Fatonah. S. (2014). Induksi Akar Pada Eksplan Tunas Anggrek Gramatophylum scriptum var. Citrinum Secara in vitro pada Media MS dengan Penambahan NAA dan BAP.

Klerk, G. J. (2006). Plant Hormones In Tissue Culture, In Duchefa Biochemie. Biochemicals Plant Cell And Tissue Culture Phytopathogy, Duchefa Biochemie BV, Haarlem. Netherlands.

Kumar, M. S Balachandran, S., Chaudhury, S. (2012). Influence of incubation temperatures on total phenolic, flavonoids content an free radical scavenging activity of callus from Heloitropium indicum L. Asia J. Pharm. Res, 2 (4): 148-152

Mandang, J. S. (2013). Media Kultur Jaringan Tanaman. Manado: Bayumedia Publishing Anggota IKAPI.

Mantell, S. H., Matthews, J. A and R. A. MC. Kee. (1983). Principles of Plant Biotechnology. An Introduction to Genetic Engineering in Plant. Blackwell Scientific Publ. London. Melbourne. P. 197-204.

Matatula, A. J. (3003). Subtitusi Media MS dengan Air Kelapa dan Gandasil-D Pada Kultur Jaringan Krisan. Eugenia 9 (4) : 203-211 
Murashige, T. (1974). Plant Propagation through Tissue Culture . Ann. rev. Plant physiol, 135-166.

Nurjanah, E. (2009). Pengaruh Kombinasi $\mathrm{NaCl}$ dan ZPT IBA pada Media MS Terhadap Pertumbuhan Galur Mutan Padi Secara In Vitro. Prodi Biologi, Fakultas Islam Negeri Syarif Hidayatullah.

Pandiangan, D., Tilaar, W., Karyono., R. R. Esyanti, dan A. Subarnas. (2011). Respons Pertumbuhan, Kadar Protein dan Aktivitas Triptofan Dekarboksilase Agregat sel (Chatarantus roseus .L). G. Don yang diberi Prekursor Triptofan. J. Bionatura Vol. 13 (1): 6-15

Rumondor, M. J., Polii-Mandang, J., Rotinsulu, W. (2013). Peningkatan Sulforafan Brokoli (Brassica Oleraceae L. Var. Italica) dengan Mondifikasi Media pada Kultur Jaringan. Mipa UNSRAT Online 2, 6065.
Septiana, A. A., Slameto., Restanto, D. P. (2014). Pengaruh Hormon IAA dan BAP Terhadap Perbanyakan Tanaman Kentang (Solanum tuberosum L.) Secara in vitor.

Tilaar, W. (2016). Mikropropagasi Brokoli (Brassica oleracea L. var. Italica Plenck) dan Peningkatan Sulforafan Selama Pembentukan Plantlet. Disertasi. Pascasarjana Universitas Brawijaya. Malang

Tilaar, W., \& Rantung, J. L. (2013). Induksi Kalus dan Tunas dar Eksplan Pucuk Brokoli dalam Media MS yang diberikan NAA dan BAP. Manado: Eugenia.

Tilaar, W., Sumeru, A., Bagyo, Y., \& PoliiMandang, J. (2012). Synthesis of Sulforaphan during the Formation of Plantlets from Broccoli (Brassica oleracea $L$ var italica) In Vitro. Manado: International Journal of Engineering \& Technology IJET-IJENS Vol: 12 No; 03. 